Шайзаданова Айдана Серікқызы, Магистрант Восточно-Казахстанский Государственный Технический Университет имени Д.Серикбаева г. Усть-Каменогорск, Казахстан E-mail: aidana_serikkyzy95@mail.ru ORCIDID 0000-0001-8475-4130

\title{
ВОЗВЕДЕНИИ ДОМОВ ИЗ ПАНЕЛИ СЕЛЕНИТ
}

\author{
Shaizadanova Aidana Serikkyzy, Magister \\ D.Serikbayev East Kazakhstan State Technical University \\ City Ust'-Kamenogorsk, Kazakhstan \\ E-mail: aidana_serikkyzy95@mail.ru \\ ORCID ID 0000-0001-8475-4130
}

\section{BUILDING HOUSES FROM THE SELENITE PANEL}

\begin{abstract}
Аннотация: Актуальность выбранной темы исследования обусловлена тем, что строительные аддитивные технологии, являясь одним из наиболее перспективных направлений, в настоящее время вызывают существенный научно-практический интерес. Сегодня строительная промышленность, возможно, стоит перед самым большим выбором будущих направлений развития.
\end{abstract}

Ключевые слова: селенит, вяжущие вещества,портланд цемент

Annotation: The relevance of the chosen research topic is due to the fact that construction additive technologies, being one of the most promising areas, are currently of considerable scientific and practical interest. Today, the construction industry may be facing the largest selection of future development directions.

Keywords: Selenite,binders, Portland cement.

Актуальность выбранной темы исследования очевидна: технологии 3D-печати завоевывают мир и это настоящая научно-техническая революция, происходящая буквально на наших глазах. Глядя на скорость претворения в обыденную жизнь идей, еще недавно фантастических, таких, как изготовление способом объемной печати протезов кистей рук человека, уже не только футурологи, но и специалисты в различных отраслях уверенно говорят о грядущих значительных изменениях в жизни человеческого общества. И если в некоторых отраслях практическая применимость 3D-печати показывает существенные достижения (медицина, ракетостроение, машиностроение, радиотехника и электроника), то в строительстве аддитивные технологии применяются для постройки единичных объектов, в своем роде «концепт-домов», «жилищ будущего» и индивидуальных (и, кстати, весьма дорогостоящих) жилых коттеджей, выполненных по индивидуальным проектам.

Селенит - морфологическая разновидность минерала гипс, отличается характерным параллельно-волокнистым строением агрегатов. В англоязычных источниках, в отличие от отечественных, термин «селенит» (Selenite) принято использовать для обозначения всех прозрачных кристаллов и агрегатов гипса, в противоположность его непрозрачным массивным разновидностям

В зависимости от способа получения гипсовые вяжущие (ГВ) вещества делятся на три основные группы: 
I - вяжущие, получаемые термической обработкой гипсового сырья: низкообжиговые (обжиговые и варочные) и высокообжиговые;

II - вяжущие, получаемые без термической обработки (безобжиговые);

III - вяжущие, получаемые смешиванием гипсовых вяжущих I или II групп с различными компонентами (минеральными и химическими).

B I группу входят: гипсовые вяжущие, основной составляющей которых является $\alpha$ - или $\beta$-полугидрат сульфата кальция (или их смесь), а также растворимый ангидрит; ангидритовые вяжущие, состоящие, главным образом, из полностью обезвоженного гипса или даже частично диссоциированного ангидрита, содержащего небольшое количество свободного оксида кальция.

Bo II группу входят: вяжущие, получаемые на основе природного двугидрата сульфата кальция; вяжущие, получаемые на основе природного ангидрита. Для активации твердения этих вяжущих вводятся специальные добавки.

В III группу входят вяжущие, получаемые смешиванием гипсовых вяжущих I и II групп с различными компонентами (известь, портландцемент и его разновидности, активные минеральные добавки, химические добавки и др.).

Вяжущие I и II групп являются неводостойкими (воздушными) гипсовыми вяжущими (НГВ). Вяжущие III группы относятся, за некоторым исключением, к водостойким гипсовым вяжущим (ВГВ).

Для производства указанных в табл. 1 гипсовых вяжущих веществ применяют природное гипсовое, ангидритовое сырье или гипсосодержащие отходы.

Гипсовые вяжущие марок Г-2..Г-5 состоящие в основном из $\beta$-полугидрата, грубого, среднего и тонкого помола (согласно ГОСТ 125), обычно называют строительным гипсом; марок Г-5...Г-25 тонкого помола - формовочным гипсом или гипсовым Вяжущим (ГВ).

Гипсовые вяжущие, состоящие преимущественно из $\alpha$-полугидрата сульфата кальция и обозначаемые маркой выше $Г-7$, часто называют высокопрочным или техническим гипсом. Гипсовые вяжущие, применяемые в хирургии и стоматологии называют медицинским гипсом. Это вяжущее должно быть марки не ниже Г-4.

Гипсовым цементом называют материал, получаемый путем тонкого помола гипсового камня совместно с активизирующими добавками или без них по сухому или мокрому способу.

Смешанные гипсовые вяжущие вещества состоят в основном из гипсовых вяжущих I или II групп, извести или портландцемента с модифицирующими минеральными и химическими добавками. Их получают путем смешивания всех компонентов или введения модифицирующих добавок в процессе производства гипсовых вяжущих.

Наибольшее распространение получили следующие виды водостойких гипсовых вяжущих:

Гипсоцементно-пуццолановое вяжущее (ГЦПВ), представляет собой смесь гипсового вяжущего марки не ниже Г-4 (50-70 \%), портландцемента или его разновидностей и активной минеральной добавки (трепел, опока, диатомит, кислые шлаки и золы, и т.п.), взятых в надлежащих соотношениях. Соотношение между портландцементом и активной минеральной добавкой определяется по методике, изложенной в ТУ 21-31-62-89. Вместо портландцемента и активной минеральной добавки можно использовать пуццолановый портландцемент с необходимым количеством активной минеральной добавки.

Панели Celenit изготавливаются из древесного волокна хвойных пород, обычно ели и добавления связующих материалов - это портландцемент и добавки (карбонат кальция). 
Благодаря волокнистой структуре (рис. 1) панели имеют хорошее звукопоглощение, а благодаря достаточной твердости и хорошую звукоизоляцию. Благодаря этим качествам Селенит можно назвать хорошим природным (экологичным) тепло- и звукоизолирующим материалом.

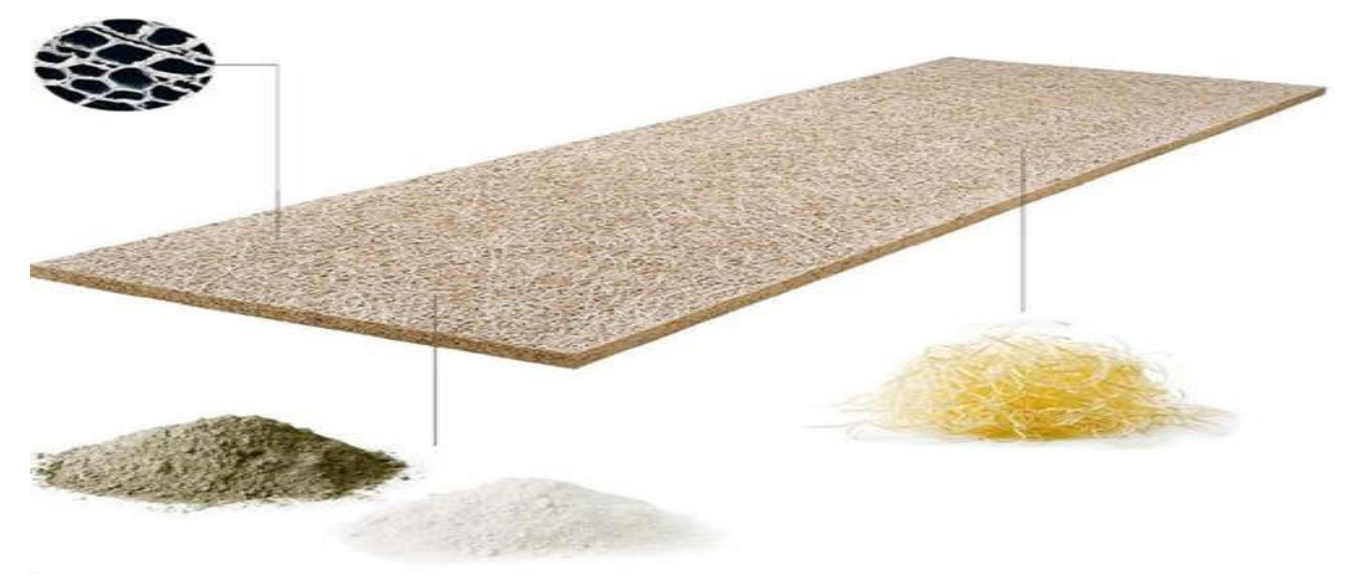

Рис.1. Структура и состав панели Celenit

1 - древесное волокно (древесная шерсть), 50\%; 2 - карбонат кальция (15\%); 3 минеральное вяжущее, обычно портландцемент (35\%); 4 - структура селенитовой панели под электронным микроскопом

Материалы и изделия из измельченной древесины обладают рядом достоинств. Их можно изготовлять требуемых размеров и свойств, выполнять при прессовании необходимые пазы, гнезда, отверстия и другие элементы, сводя к минимуму механическую обработку. Меняя технологические параметры и количество связующего, можно регулировать свойства получаемых изделий и производить детали с облицованной поверхностью.

Для приготовления древесно-клеевой композиции измельченную древесину смешивают со связующим. Далее древесно-клеевую массу загружают в пресс-формы, внутренние поверхности которых покрывают смазочным материалом для предотвращения прилипания к ним прессуемого материала. При необходимости в пресс-форму укладывают облицовочный материал и крепежную арматуру.

Основными параметрами, управляющими процессом прессования, являются температура прессования, влажность пресс-массы и время выдержки в прессе. Прессование ведут при температуре 120-160 С и давлении 2 - 20 МПа в зависимости от требуемой плотности изделия.

Облицовывание предназначено для улучшения декоративных свойств поверхности, повышения прочности деталей, создания покрытия, защищающего от выделения токсических веществ (например, облицовывание древесностружечных плит).

Облицовывание может быть односторонним, когда облицовочный материал наклеивается на одну сторону, и двухсторонним. Его можно выполнять в один слой, т.е. когда облицовочный материал наклеивается непосредственно на основу, и в два слоя, т.е. с подслоем. Щитовые детали облицовывают, как правило, с обеих сторон.

Процесс облицовывания включает следующие стадии: подготовку основы, подготовку облицовки, приклеивание облицовки к основе, технологическую выдержку после облицовывания.

По характеру статической работы в здании панели стеновые делятся на несущие,

Строительная механика - селенит
Материалы Международной практической интернет-конференции «Актуальные Проблемы Науки» 
самонесущие и навесные;

по конструктивному признаку - на однослойные и многослойные (двух — и трехслойные).

К конструкциям стеновых панелей предъявяется ряд эксплуатационных, технологических и технико-экономических требований: термическое сопротивление, защита от перегрева помещений летом, непродуваемость, защита от проникновения влаги, минимальный вес и толщина, возможность механизации изготовления, транспортабельность, максимальная заводская готовность, минимальная трудоемкость изготовления и монтажа, расход основных материалов, стоимость и т. д.

Наиболее технологичными в изготовлении следует считать однослойные панели. Многослойные панели (сэндвич панели) при изготовлении отличаются многодельностью, трудностью механизации основных операций и, следовательно, большой трудоемкостью, но имеют меньший вес 1 м2 и другие технико-экономические достоинства. Однослойные панели делаются из легких бетонов на пористых заполнителях (шлак, аглопорит, керамзит, пенокералит, перлит и т. д.) и из ячеистых бетонов (пено - и газобетон,). Двуслойные панели готовятся в виде ребристых плит из железобетона, утепленных с внутренней стороны эффективным утеплителем (пенобетон, пеностекло, пенокералит, минераловатные плиты и др. материалы), из плотного и крупнопористого керамзитобетона и т. д. Трехслойные панели состоят из двух плоских древесноволокнистых плит с эффективными утеплителями между ними (обычно пенполистирол).

\section{СПИСОК ЛИТЕРАТУРЫ}

1. Антонова В.С. Аддитивные технологии: учебное пособие / В.С. Антонова, И.И. Осовская. - СПб.: ВШТЭ СПбГУПТД, 2017. - 30 с.

2. Дьяченко В.А. Материалы и процессы аддитивных технологий (быстрое прототипирование) / В.А. Дьяченко, И.Б. Челпанов, С.О. Никифоров. - Улан-У дэ: Изд-во БНЦ СО РАН, 2015. - 198 с.

3. Зленко М. А. Аддитивные технологии в машиностроении: пособие для инженеров / М.А. Зленко, М.В. Нагайцев, В.М. Довбыш. - М.: ГНЦ РФ ФГУП «НАМИ», 2015. - 220 с.

4. Максимов Н.М. Аддитивные технологии в строительстве: оборудование и материалы // Н.М. Максимов / Аддитивные технологии. - №4 - 2017. - С. 54 - 62.

5. Максимов Н.М. Аддитивные технологии в строительстве: примеры и перспективы применения // Н.М. Максимов / Аддитивные технологии. - №1 - 2018. - С. 36 - 42. 